\title{
"Our Little Parish of St. James's": Centrality, Orthodoxy and Self-Reflexivity in the 1890s London Theatre
}

\section{Rudolf Weiss}

In the 1890 s the London theatre was governed by the idea of centrality. This most representative and most prestigious theatrical territory was ruled by the actor-manager, the monocratic director who also played the leading roles. Moreover, he was the arbiter in matters of dramatic aesthetics, in matters of dramatic ethics as well as audience reception. Henry Arthur Fones and Arthur Wing Pinero, the most popular playwrights of the period, provided them with leading parts which reflect their managerial functions in the dramatic world: the raisonneurs in their society dramas manipulate the action, advise the other characters and represent social and moral orthodoxy. The article explores the concept of centrality in the London theatre of the 1890 on various interconnected levels - theatre management, dramatic technique, functions of the raisonneur and ideological implications of the scène à faire as well as audience structure and audience taste. A special focus is placed on the essential (self)reflexivity of this "little parish", where the managerial structures of the mainstream theatre are mirrored in the conventional dramatic aesthetics of society drama, the predominant genre in the repertoire, which echoes the mind-set of the majority of the spectators.

\section{Introduction: the authority of the actor-manager}

In her introductory chapter to The Cambridge Companion to Victorian and Edwardian Theatre Nina Auerbach claims that all the contributions in this volume "insist on the centrality of the theatre in nineteenth-century culture; until the end of the century, its broad popularity gave its conventions the aura of universality" (4). This central importance of the stage is linked with a self-reflexive function, as the theatre was "the prism through which all Victorian artists and audiences - and these were most Victorians - saw their world" (Auerbach 3). Within this wider context the microcosm of the "little parish of St. James's" is the epitome of centrality (Pinero, The Second Mrs. Tanqueray 75). The elitist parishioners, representing Victorian orthodoxy, 
considered their social space as the centre of the universe, a world governed by conventional morality, social and political conformism, and mainstream aesthetics. They found their domain reflected in the London West End theatre, which gratified the parishioners's inclination towards narcissism.

The idea of centrality was at the heart of theatreland, as the most significant and influential theatrical landscape of London, and of Great Britain. Moreover, the theatre of the 189 os was dominated by the all-powerful actor-manager, a prominent actor who leased a theatre, set up a permanent company and produced plays of his own choice, in which he usually played the best roles. He was also the arbiter in matters of dramatic construction, in matters of moral standards as well as audience expectations. In other words, the entire process of theatrical production was in the hands of one individual, an autocrat, all-powerful but also fully responsible.

Henry Irving reigned supreme at the Lyceum, Herbert Beerbohm-Tree at His Majesty's, Charles Hawtrey at the Comedy, Cyril Maude at the Haymarket, and John Hare at the Garrick. Two of the most popular among late Victorian actor-managers, who also had close connections with successful dramatists of their day, were George Alexander of the St. James's and Charles Wyndham of the Criterion and later of his own Wyndham's Theatre. The actor-manager, the director who pulled the strings of the entire theatrical enterprise, also had a very strong position vis-à-vis the dramatist. For example, Alexander urgently suggested revisions to Oscar Wilde both before and after first producing Lady Windermere's Fan in 1891. For example, the actor-manager demanded a different curtain-line for Act Two (Raby 83) and a more far-reaching structural revision: "[...] the fact of Mrs Erlynne being Lady Windermere's mother should be revealed early in the play, rather than held back until Act Four" (Raby 84). This essential change was made during the first run of the play, "on the fourth or the fifth night" (Raby 84). This underlines how important this adjustment was to Alexander and how promptly Wilde complied with the director's wishes. When Alexander received the first version of The Importance of Being Earnest, he asked for an even more radical reworking: he advised Wilde "to reduce his four-act structure to three acts". As Peter Raby argues, "[t]here can be no doubt $[\ldots]$ that the three-act structure which Wilde produced for Alexander is infinitely more effective" (121). Wyndham's criticism of Henry Arthur Jones's The Case of Rebellious Susan was primarily of a commercial kind, although disguised as moral outrage. In this play Lady Susan threatens to retaliate upon her unfaithful husband in kind. The key question here is the nature of the romantic involvement of Lady Susan with Lucien Edensor. 
Although the allusions in the text were ambiguous, Wyndham was appalled at what he saw as fairly explicit references to an illicit relationship. This is the incriminated passage of dialogue:

LADY SUSAN: You're sure nobody suspected?

LUCIEN: How could they?

LADY SUSAN: Oh, I should kill myself if anyone knew! You have never spoken of me - boasted to any of your men friends - ? (129)

In a letter to Jones, Wyndham complained bitterly about the outspokenness of Lady Susan's last speech and the implied immorality as well as the dramatist's tolerance of this highly unethical conduct: "I stand as bewildered today as ever at finding an author, a clean-living, clear-minded man, hoping to extract laughter from an audience on the score of a woman's impurity" (quoted in Jones, Doris 164). This can pass as moral indignation. However, Wyndham very soon takes a different direction and voices the fears of the actor-manager to irritate or even offend his audience, with detrimental effects on the boxoffice returns:

I am astonished at a practical long-experienced dramatic author believing that he will induce married men to bring their wives to a theatre to learn the lesson that their wives can descend to such nastiness, as giving themselves up for an evening of adulterous pleasure and then return safely to their husband's arms provided they are clever enough, low enough, and dishonest enough to avoid being found out? (quoted in Jones, Doris 164-5)

It appears that a crucial remark in this letter not only indicates the representative function of the actor-manager and his knowledge of the sensibilities of his spectators, but also sounds very much like a quotation from the raisonneur's speech in one of Jones's comedies: "I am not speaking as a moralist, I am simply voicing the public instinct" (quoted in Jones, Doris 166).

The conflict between dramatist and actor-manager was finally resolved by cutting the parts of Lady Susan's speech which, in Wyndham's view, clearly referred to a relationship that went beyond flirtation and rewriting it to read: "You have never spoken of me to any of your men friends?" (quoted in Jones, Doris, 162-3) However, Jones later restored the original dialogue in the printed version of the text, also adding a satirical dedication "To Mrs Grundy", the unseen but ever present guardian of morals (105-7), in which he 
expresses his irritation with the prudery of his audiences and, significantly, of the actor-managers.

It is interesting to note that Wyndham was excessively concerned that female members of his audience may be embarrassed, offended or even corrupted by the unconventional behaviour of female characters in Jones's plays, while he appears to have been quite happy to indulge in the raisonneur's repeated misogynist diatribes, which he seems to have regarded as entirely inoffensive.

\section{Actor-manager, audience and orthodoxy}

As the actor-manager worked in the context of the commercial theatre, questions of audience structure, of audience taste, of audience response were of prime importance to him. Russell Jackson claims that

West End theatres were never completely insulated from society with a small 's', and it is a mistake to think of them as playing to a homogeneous middle- and upper-class audience. The masses and the classes were not wholly separated, even though theatre architects did their best by providing separate entrances and box-offices. ("Importance" 162)

However, Jackson also reminds us that the St. James's Theatre was "as well ordered as a drawing-room" and that, according to Lady Alexander, the "first nights seemed [...] 'like brilliant parties"” ("Importance" 162). Essentially, as far as we are familiar with Victorian West End audiences, it is fairly safe to say that, socially, they mainly belonged to the upper and the upper-middle classes, in terms of taste they were catholic, in terms of morals they were conformist, and in terms of their reception habits, they expected to be entertained with plays which were tailored to their liking. As early as 1877 Henry James described this type of audience less than favourably as "well dressed, tranquil, motionless; it suggests domestic virtue and comfortable homes; it looks as if it has come to the play in its own carriage, after a dinner of beef and pudding" (quoted in Chothia, 24). The title of Macqueen-Pope's history of the Edwardian theatre - Carriages at Eleven - indicates that neither the social standing of the spectators at the West End theatres nor their habits changed over several decades. In the 1890 s, as Jean Chothia knows, "fashionable society patronised the smartest theatres, where, increasingly, they found their manners and style 
reflected" (24). On the one hand, this refers to the splendour of the theatrical environment. For example, George Rowell offers the following comment on the interrelation between an actor-manager's style and the type of theatre he ran: "[George Alexander's] theatre was well chosen, for under his direction it took on the appearance and even character of an exclusive St. James's Street club, both front-of-house and backstage" (94). On the other hand, the echoing effect also concerns the subject matter and the language of the plays. Ian Clarke defines this interconnection between the agents in the theatrical field and its reflexive dimension as a social phenomenon:

The demonstrable class-consciousness of the theatre as an institution, which the actor manager at its head fostered and in part created, demanded that he should represent on stage a reflection of the social status of the highest section of the audience or the highest point to which it could reasonably aspire. The appropriateness of this image was shared both by the actor manager and his audience. (6)

The repertoire of plays consisted mainly of conventional dramatic fare, generically as well as thematically. The intended reception perspective was clearly geared towards a promotion of traditional social and moral norms, which were dear to the majority of spectators. The preferred genre had many names: well-made play, problem-play, society drama, society comedy, drawingroom drama, drawing room comedy. The society drama, in its serious as well its comic variety, is predominantly peopled with titled characters and figures from the upper middle class who, more often than not, live on unearned income.

The Victorian key concepts of respectability and social decorum are at the thematic centre of Jones's society dramas. With reference to their prime mission in the first two comedies Wendy Trewin labels the raisonneurs "marriageguidance counsellor[s]" (138). Although the reconciliation of errant marriagepartners is one of the essential functions of the raisonneurs, invariably on the basis of the double standard of morality, there are other contemporaneous ideological issues which inform these society plays, and which are reflected in them. Misogyny, the constant demand to do one's duty, and patriotism, to serve one's country, particularly as an empire-builder or a defender of the empire, are prime examples. For instance, Sir Christopher in The Liars keeps spouting misogynist slogans in the manner of an itinerant preacher, foregrounding the inferiority and worthlessness of women. In the raisonneur's view they are "[a] kind of children, you know. Humour them, play with them, 
buy them the toys they cry for, but don't get angry with them. They aren't worth it!" (212). This is a slight variation of his earlier piece of advice: "Love 'em, worship 'em, make the most of 'em! ... But don't break your heart over 'em! Don't ruin your career for 'em! Don't lose a night's rest for 'em! They aren't worth it ...!" (192) In the same vein are his recommendations to the husbands. In order to put the marital relations on a new footing he suggests taking their wives to an excellent restaurant, taking them on holiday to the continent and/or buying them jewellery. The men who become entangled with the married women in the plays also have to bear the counselling of the worldy-wise know-all. However, the raisonneur's propositions for alternatives are much more serious and consequential. Lucien Edensor, the young man who falls in love with Lady Susan, is sent off to do his imperial duty in New Zealand. Edward Falkner, the romantic lover in The Liars, is of a different order altogether. He is a hero who has earned the nation's gratitude by successfully fighting slave-traders in Africa. Exactly at the moment when he is about to upset the social equilibrium of the parish of St. James's by eloping with the married Lady Jessica, there is, conveniently, a new outbreak of violence in Africa and the empire urgently needs the services of the national hero. Now it is Falkner's dilemma to have to choose between love and duty, very much like the protagonist of the heroic drama of the late seventeenth century. Again, it is the raisonneur who urges Falkner to do his duty and who manages to persuade him to give up Lady Jessica and return to Africa. Another significant facet of the opposition between sexual morality and dutiful, heroic service to the empire is explored in Arthur Wing Pinero's The Second Mrs. Tanqueray. Ellean, the innocent daughter of Aubrey Tanqueray falls in love with Captain Ardale, a military man, who has accomplished feats of heroism in India, but has also lived what was called a man's life. Angelic Ellean forgives Ardale his moral transgressions on account of "his wonderful heroism" as a defender of the empire: "Face to face with death for a whole week; always with a smile and cheering word for the poor helpless souls depending on him!" (114). On the other hand, Ellean condemns one of the victims of Ardale's wild life, her step-mother Paula, mercilessly and relentlessly. Essentially, the ideological implication of the treatment of this motivic material in the society drama is a male-oriented value system. By performing their duty, preferably their imperial duty, errant men must be forgiven their dishonourable moral conduct, while women, whose sole duty it was to remain innocent before and faithful after marriage, had to face severe consequences when they deviated from the path of virtue, without any alternative course to remedy even minimal transgressions. 
With Ian Clarke, we can conclude that "[t]he drama is deliberately organized, in its formal construction and systems of ethical validation, so as to be instrumental in endorsing orthodox ideological assumptions" (28).

\section{Actor-manager, raisonneur and self-reflexivity}

Society drama, then, mirrors the value system of the social elite. It is the raisonneur, particularly in Jones's comedies, who propagates this in the world of the plays. This central figure in the society drama is invested with a superior perspective on account of his personality and his position among the dramatis personae. The raisonneur, the mouthpiece of society rather than that of the author, represents and promotes the ethical code of the haut monde, of the parishioners of St. James's. In a seminal dialogue between the male protagonist Aubrey Tanqueray and the raisonneur Cayley Drummle in an early scene of Pinero's The Second Mrs. Tanqueray the dimensions and delimitations of the parish are determined and questioned at the same time:

AUBREY: ... yours is the way of the world.

DRUMMLE: My dear Aubrey, I live in the world.

AUBREY: The name we give our little parish of St. James's. (75)

While the raisonneur prefers to look on the parochial world of St. James's as the world at large, or, implicitly, as the centre of the world, Aubrey clearly sees the pretensions and limitations of this social space. In terms of Pinero's play, which was first performed at the temple, at the heart of the parish, the highly fashionable St. James's Theatre, this may also ironically refer to the limitations of the dramatic world.

Russell Jackson describes the raisonneurs in Jones's society comedies in the following way:

All are supposed to possess authority in the world as confirmation of their function as raisonneur in the play: Kato and Carteret are lawyers, Deering a military man. It is their experience and wisdom, rather than any special idealism, that has entitled them to this authority and to the audience's respect. (Introduction 14) 
On the other hand, Cayley Drummle defines his own role in the dramatic world of The Second Mrs. Tanqueray in metatheatrical terms:

And remember that, after all, I'm merely a spectator in life; nothing more than a man at a play, in fact; only, like the old-fashioned playgoer, I like to see certain characters happy and comfortable at the finish. $(76)$

Wearing also calls attention to the implications of these references for the dramatic and theatrical production and reception process in the wider context of the response to the protagonists of the play:

The metatheatrical element here underscores Drummle's words, and adds complexity to his function as a traditional raisonneur [...]. Drummle is both observer and participant, commentator and actor. He is, like the St. James's audience, a playgoer, and Pinero intimates that Drummle's desire for a happy outcome espouses the audience's wish. That can be achieved only if Aubrey and Paula are embraced by the very society concurrently serving as observers. (Introduction 23)

The relation between the actor-manager in the theatrical world and the raisonneur in the dramatic world should also be viewed from the perspective of self-reflexivity: The actor-manager's representative in the society drama is the raisonneur. The raisonneur attempts to manipulate the action, to take control of the interaction of the characters and assumes the role of their confidant and adviser. In terms of the ideology of the plays he can be regarded as the mouthpiece of society, of upper and upper middle-class society. He advocates traditional social and moral norms and warns against any breaches of the code and against inevitable repercussions, the most severe being the expulsion from the parish of the decent and fashionable. One or the other raisonneur may have his doubts about the validity of the rules. However, as a man of the world, he knows that one has to play by the rules nevertheless. And this is exactly what he recommends to those who are about to break the rules: You do not have to believe in their ethical value, you only have to observe them. Essentially, he advises them to engage in societal role-playing, how to perform in what may be seen as the social theatre, as, for example, Sir Christopher Deering in The Liars: "You know, what we English are, Ned. We're not a bit better than our neighbours, but thank God! We do pretend we are, and we do make it hot for anybody who disturbs the holy pretence" (215). 
Conversely, these functions of the raisonneur in the dramatic realm mirror those of the actor-manager in the real world, in the theatrical world. One may say that he instructs his actors how to perform, he prescribes the rules by which the actors have to abide, he gives directions as to their interaction, and, urges them to stick to the text, the norms of the dramatic world.

We arrive at a further level of self-reflexivity when the actor-manager himself plays the role of his inner-textual representative, that of the raisonneur. A further reflexive dimension is added, or self-referentiality has come full circle, when the dramatist writes this role for a particular actor-manager, as did Henry Arthur Jones for Charles Wyndham. Jones wrote the leading parts in his society comedies for Wyndham: Sir Richard Kato in The Case of Rebellious Susan (1894), Colonel Sir Christopher Deering in The Liars (1897) and Sir Daniel Carteret in Mrs. Dane's Defence (1900).

\section{Structure and Centrality: the scène à faire}

The notion of centrality also governs the structure of the plays performed for the parish. In terms of construction all the varieties of late Victorian society drama are well-made plays. At the structural centre of the formula of the wellmade play the scène a faire, the obligatory scene, is located, a scene towards which the development of the action is geared and which the audience is manipulated to expect. Conventionally, in this scene the fate of the protagonist takes a decisive turn, the repercussions of which are then presented in the dénouement.

Douglas Cardwell defines the scene at the centre of the well-made play of the Scribean type in the following way:

The action also includes situations, known as scènes à faires, that the audience longs for but regards as uncertain, or dreads but believes to be unavoidable. They usually involve a direct confrontation between protagonist and antagonist, or their representatives, from which one will emerge the victor (at least provisionally). The scène à faire generally comes fairly late in the action and points the way to the dénouement. (878)

Foremost among English dramatists who adopted and adapted the well-made play for the London stage were Henry Arthur Jones and Arthur Wing Pinero, the most popular dramatists of the late Victorian theatre. Their 
work was central to the repertoire of the commercial theatre of the 189os. The statistics we find in Ian Clarke's study of the Edwardian drama, speak a clear language. Between 1890 und 1899 the London stage saw 2056 performances of plays by Jones and 2478 by Pinero (22). Their stage works also feature prominently in Play-Making: A Manual of Craftsmanship, a handbook for writing, essentially, well-made plays by the influential critic, translator and playwright William Archer. The self-named apologist for "the theatrical theatre" (147), introduced the term "obligatory scene" (his own translation for scène à faire) into the critical discourse. With reference to the nineteenth-century French journalist and dramatic critic Francisque Sarcey, Archer defines this central scene as follows: "An obligatory scene is one which the audience (more or less clearly and consciously) foresees and desires, and the absence of which it may with reason resent" (148). In their variety of the well-made play, Jones and Pinero introduce a problem, usually of a social nature, which is explored yet never solved. More often than not this concerns the social and moral norms of the section of society among which the play is set and which constitutes the majority of the audience. The rules and conventions of the upper-middle and the upper classes are examined, questioned, but never discarded. Although the obligatory scene retains its crucial function in the development of the action, it is additionally invested with a thematic significance. The central scene does not only stage the decisive confrontation between protagonist and antagonist but also highlights the underlying conceptual issues and determines the affirmation of the norms of the ruling classes. It is a distinctive feature of the well-made problem-plays of Jones and Pinero that the obligatory scene does not only signal the highest point of tension but also the ultimate stage of departure from the Victorian mainstream. Simultaneously, it is the point of reversal, marking the shift of direction back to conventionalism.

We can find impressive obligatory scenes in several plays of the 189 os by Henry Arthur Jones, for example in The Liars, first performed in 1897. At the end of the third act the intricate edifice of lies fabricated in order to cover up the flirtation of the married Lady Jessica with Edward Falkner shows acute symptoms of collapsing. Although the audience has watched, with increasing concern and suspense, the growing complexity of the deception as well as the growing number of liars involved, the climax does come as a surprise:

JESS (rises very quietly). Mr. Falkner, tell my husband the truth. FALKNER. But, Lady Jessica - 
JESS. Yes, if you please - the truth, the whole truth, and nothing but the truth. Tell him all. I wish it. (209)

In this crucial scene at the structural and thematic centre of the play the charming, attentive and passionate admirer of a married woman faces the lawful husband, who is boorish, inelegant, lacks any sense of humour and neglects his attractive wife. While in terms of personal appeal the sympathy of the audience may be with Falkner, in terms of the key issues at stake, the Victorian sacred cows of propriety and decorum, the husband is certainly in a superior position. Here the problem of upsetting the social and moral equilibrium is highlighted. This scene, in which the gallant publicly declares his love for a married woman, marks the furthest point of deviation from the accepted norms. It will be the duty of the raisonneur, in the fourth act, to bring Falkner and Lady Jessica to their senses, to conform to the written and unwritten laws of society, to bring them back into the parish.

Arguably the best example of an obligatory scene in late Victorian drama is the cross-examination scene in Jones's Mrs. Dane's Defence, first staged in 1900. Like so many other plays of the period it deals with the attempted reintegration of a woman with a past into polite society. After suspicions have been voiced that the attractive widow Mrs. Dane is actually Felicia Hindemarsh, who was involved in a scandal, the plot of the play centres on determining the true identity of the title figure. When Lionel Carteret, the (adopted) son of the eminent judge Sir Daniel Carteret, the raisonneur in the play, intends to marry Mrs. Dane, her name has to be cleared. Eventually, in the third act, Mrs. Dane accepts Sir Daniel's help in reviewing the evidence with her, with a view to establishing her innocence. However, towards the end of this interview, which gradually turns into a cross-examination, Sir Daniel challenges the desperately struggling heroine in no uncertain terms: "I say you're lying! You are Felicia Hindemarsh!" (253), an indictment which is followed by the full confession of the protagonist. This decisive moment in the development of the action as well as in the fortune of Mrs. Dane also marks the utmost limit of the existence of a fallen woman in polite society. In this confrontation between the raisonneur, the spokesman and representative of society's norms, and the heroine, who endeavours to circumvent the ruling code, even in 1900, almost at the end of the Victorian period, the validity of the dominant ideology is emphatically endorsed. Mrs. Dane/Felicia Hindemarsh has to give up Lionel and leaves the community. As a concession to the emerging liberalism of a new age, Jones spares the transgressing heroine a public exposure. 
Another third-act obligatory scene with ideological overtones can be found in Pinero's drama in four acts of 1893, The Second Mrs. Tanqueray. Paula, the quintessential woman with a past of the nineties, marries the widower Aubrey Tanqueray in an attempt to start a new, respectable, life. The troubled marriage is seriously blighted by the shadows of the past of the protagonists, particularly by the polarity between Paula's character, which appears to have been tainted by her earlier unconventional life, and Aubrey's past, in the person of Ellean, his innocent and over-religious daughter by his first marriage. In the obligatory scene these two opposites join forces to destroy the ambitions of the eponymous heroine. Ellean has fallen in love with Ardale, one of Paula's former lovers. With Ardale's reentry into her life, the embodied presence of the past, the heroine's experiment in marriage collapses. The social law, as represented in the Victorian problem play, does not allow a fallen woman to succeed. The irony of the scene lies in the highlighting of the prevalent double standard of morality. While Ardale, the man with a past, is readily forgiven, the woman with a past has to face the consequences, an "inescapable pattern" which Anthony Jenkins aptly defines as follows: "Paula rails against the fact that Ellean could forgive Ardale, because of his military heroism, but Pinero ultimately implies that the code of St James's reflects the law of Nature" (179).

In his next problem play, The Notorious Mrs. Ebbsmith, of 1895, Pinero moves further into highly contested territory by challenging the essential tenets of Victorian morality, with the institution of marriage at the centre of his criticism. Agnes Ebbsmith, the protagonist with radical views on gender politics, enters a "free union" with a married man. Put under pressure from various sides, disappointed with her partner and herself, angry, frustrated, unconsoled by Christian doctrine, Agnes throws the Bible into the fire. After a moment of shock she retrieves the holy book. In this obligatory scene, the central issues of the play, and of Victorian society, are negotiated in symbolic and highly theatrical terms. Agnes, feminist, socialist, radical, has not only reached the extreme limit of her experimental and provocative endeavour, she has actually passed it. In this emblematic scène à faire the Bible, the symbol of the foundations of the Victorian world, is furiously disposed of and almost simultaneously reinstated, "its authority reinscribed" (Wozniak 403), the governing rules and moral codes denied and affirmed at the same time. In the fourth act, the penitant heroine fully embraces convention again. In her convincing defence of Pinero, with reference to the authorial intentions concerning the Bible-burning scene, Wozniak argues that "he wants to show 
the subtle and debilitating effects of that morality - a more powerful incentive to rethink social mores than a simplistic rejection of them would inspire" (405).

\section{Conclusion: fin-de siècle and beyond}

This self-regarding, self-reflexive, one might even say narcissistic, mind-set of the parishioners of St. James's is also at the centre of the society dramas successfully performed at the fashionable theatres of central London. It appears that the fin-de-siècle elite derived great pleasure from representations of itself. This inward-turning attitude is typical of decadent societies in quasi-apocalyptic eras, with the exceptionally long Victorian age coming to an end, the new century looming, and the Great War not too far off.

Although, essentially, society drama, through its ideological spokesman, the raisonneur, affirms the values of the dominant class, in a few instances the dramatists probe the limits of deviance from the predominant code. It is frequently the romantic hero who questions the validity of ideological constructs as represented by "the man of the world". Confronted by Deering, the raisonneur, for making love to a married woman, and called upon to deal with the problem like a man of the world, Edward Falkner angrily rejects this concept: "Men of the world! If there is one beast in all the loathsome fauna of civilisation that I hate and despise, it is a man of the world! Good heavens, what men! what a world!" (177). In Mrs. Dane's Defence the raisonneur is faced with an intelligent, self-confident partner, Lady Eastney, who openly and convincingly questions his moral and social values.

Perhaps, one may say, Pinero goes one step further. Cayley Drummle, the worldly-wise friend of the Tanquerays, ultimately turns out to be responsible for the final catastrophe on account of his well-meaning, yet ill-advised interference, which entirely discredits the values the raisonneur stands for. In the early years of the Edwardian era Pinero produced his last well-made masterpiece, His House in Order, first staged by George Alexander at the St. James's Theatre in 1906, who also played the role of the raisonneur, Hilary Jesson. Although His House in Order is a typical well-made play and the expectations of the audience are clearly directed towards a climactic confrontation between the female protagonist and her antagonists, the audience is denied a scène à faire. We may argue that this conspicuous absence of the obligatory scene, at the structural and thematic centre, indicates a new tendency to de-centre and to de-theatricalize in the new century. In terms of the reception of Jones and 
Pinero, Penny Griffin maintains that "[a]s society changed, $[\ldots]$ Jones $[\ldots]$ grew old-fashioned. Pinero [...] simply became unpopular" (20).

Already in the 18 gos there were some efforts to establish an alternative theatre scene, yet, only after the turn of the century did new forms of theatre management, new theatrical practices emerge, producing plays which took a more critical view, not only of the social elite but also of wider segments of society.

\section{Works Cited}

Archer, William. Play-Making: A Manual of Craftsmanship. $3^{\text {rd }}$ ed. London: Chapman and Hall, 1926.

Auerbach, Nina. "Before the Curtain." The Cambridge Companion to Victorian and Edwardian Theatre. Ed. Kerry Powell. Cambridge: CUP, 2004. 3-14.

Cardwell, Douglas. "The Well-Made Play of Eugène Scribe." French Review 56 (1983): 876-84.

Chothia, Jean. English Drama of the Early Modern Period 189o - 1940. London: Longman, 1996.

Clarke, Ian. Edwardian Drama. London: Faber and Faber, 1989.

Griffin, Penny. Arthur Wing Pinero and Henry Arthur fones. London: Macmillan, 1991.

Jackson, Russell. "The Importance of Being Earnest." The Cambridge Companion to Oscar Wilde. Ed. Pater Raby. Cambridge: CUP, 1997. 161-77.

Jenkins, Anthony. The Making of Victorian Drama. Cambridge: CUP, 1991.

Jones, Doris Arthur. The Life and Letters of Henry Arthur Jones. London: Victor Gollancz, 1930.

Jones, Henry Arthur. The Case of Rebellious Susan. Plays by Henry Arthur Fones. Ed. Russell Jackson. Cambridge: CUP, 1982. 105-61.

---. Mrs. Dane's Defence. Representative Plays by Henry Arthur Fones. Ed. Clayton Hamilton. Vol. 3. New York: Macmillan, 1925. 179-273.

---. The Liars. Plays by Henry Arthur Fones. Ed. Russell Jackson. Cambridge: CUP, 1982. 163-219.

Macqueen-Pope, Walter. Carriages at Eleven: The Story of the Edwardian Theatre. 1947. New ed. London: Hale, 1972.

Pinero, Arthur Wing. The Notorious Mrs Ebbsmith. 'The New Woman' and Other Emancipated Woman Plays. Ed. Jean Chothia. Oxford: OUP, 1998. 61-134.

--. The Second Mrs Tanqueray. Ed. J. P. Wearing. Toronto: Broadview Editions, 2008. 
--. His House in Order. The Social Plays of Arthur Wing Pinero. Ed. Clayton Hamilton. Vol. 3. 1919. New York: AMS P., 1967. 253-449.

Raby, Peter. Oscar Wilde. Cambridge, CUP, 1988.

Rowell, George. Theatre in the Age of Irving. Oxford: Blackwell, 1981.

Trewin, Wendy. All on Stage: Charles Wyndham and the Alberys. London: Harrap, 1980.

Wearing, J. P. Introduction. The Second Mrs. Tanqueray. By Arthur Wing Pinero. Ed. J. P. Wearing. Toronto: Broadview Editions, 2008. 8-49.

Wozniak, Heather Anne. "The Play With a Past: Arthur Wing Pinero's New Drama." Victorian Literature and Culture 37 (2009): 391-409. 